\title{
Rekonstruksi dan Manipulasi Simbol Kecantikan
}

\author{
Intan Permata Sari
}

\author{
IAIN Bengkulu \\ Jl. Raden Fatah Pagar Dewa Kota Bengkulu
}

\begin{abstract}
Reconstruction and Manipulation of Beauty symbol. Every woman certainly dreams of having a beauty that can be glorified by the men. It's just that now the meaning of natural beauty seems to be erased by capitalist advertisements. Beautiful is white, straight hair, wide-eyed, sharp nose, and so forth. This causes women to compete in changing what God has given. Construction of the meaning and symbol of beauty is not just accepted by society. There must be processes that go through it. Berger said that there are three processes, namely: 1) externalization processes that are part of the process of creating reality in various forms. 2) Objectivation process which is the process of integrating values into objective social facts that can be accepted by the public. 3) The construction process is related to the process of internalization which is a stage to make knowledge, values and actions belong to individuals that give birth to commitment to individual attitudes and behaviors (Berger and Luckmann, 1979). This large construction is not directly agreed upon by the beauty industries around the world.
\end{abstract}

Abstrak: setiap wanita pastinya bermimpi memiliki kecantikan yang dapat diagung-agungkan oleh kaum adam. Hanya saja saat ini makna kecantikan alami seolah terhapus oleh iklan-iklan kapitalis. Cantik itu putih, rambut lurus, bermata lebar, berhidung mancung, dan lain sebagainya. Hal ini menyebabkan para wanita berlomba-lomba mengubah apa yang sudah dianugerahkan oleh Tuhan. Konstruksi makna dan simbol kecantikan tidak begitu saja diterima oleh masyarakat. Harus ada proses-proses yang dilewatinya. Berger mengatakan bahwa ada tiga proses, yaitu : 1) proses eksternalisasi yang menjadi bagian dari proses penciptaan realitas dalam berbagai bentuk. 2) Proses objektivasi yang merupakan proses integrasi nilai ke dalam fakta sosial objektif yang dapat diterima oleh publik. 3) Proses konstruksi terkait dengan proses internalisasi yang merupakan tahapan untuk 
menjadikan pengetahuan, nilai dan tindakan menjadi milik individu yang melahirkan komitmen sikap dan perilaku individual (Berger dan Luckmann, 1979). Konstruksi besar ini secara tidak langsung disepakati oleh industri-industri kecantikan seluruh dunia.

Pendahuluan

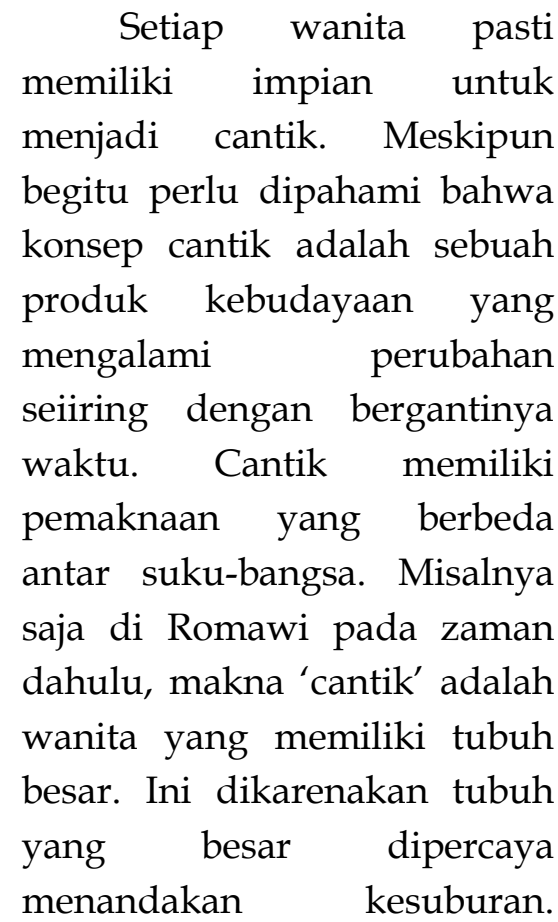
Semakin besar tubuh wanita, maka semakin cantik wanita tersebut di mata laki-laki mereka. Berbeda lagi dengan masyarakat Kayan, mereka mengakui kecantikan seorang wanita bila si wanita memiliki leher yang semakin panjang. Untuk itu, wanita pada masyarakat ini mulai umur lima tahun sudah diberikan kumparan besi yang ditaruh di lehernya. Di Cina, wanita yang dinilai cantik adalah wanita yang memiliki ukuran kaki yang kecil sehingga mereka rela menggunakan ukuran sepatu yang lebih kecil dari ukuran kaki sebenarnya agar terlihat lebih cantik.

Akan tetapi dalam dunia moderen ini, di mana pengaruh media begitu besar dalam mengkonstruksi makna kecantikan bagi wanita sehingga makna kecantikan mulai mengalami generalisasi. Makna cantik bagi seluruh masyarakat di dunia mulai bergeser menjadi putih, langsing, rambut panjang, dan muka yang bebas jerawat. Konstruksi makna oleh media ini bukanlah bebas makna, mereka memiliki rencana yang lebih besar karena ada kepentingan industri kapitalis yang bermain di dalamnya. Misalnya saja makna cantik ala dunia moderen ini diberlakukan di Indonesia, maka tidak banyak masyarakat Indonesia yang digolongkan sebagai wanita cantik karena 
mayoritas kulit masyarakat Indonesia adalah sawo matang dan mayoritas wanita Indonesia tidak memiliki tinggi tubuh yang semapai.

Di sinilah peran industri kapitalis bermain. Para industri kapitalis ini mendirikan berbagai macam salon dan klinik kecantikan yang berisi dokter-dokter spesialis kulit dan teknologi yang canggih sehingga memungkin wanita Indonesia menjadi putih, tinggi, langsing, kulit mulus, dan lain sebagainya. Akan tetapi perlu dipahami bahwa fenomena ini hanya akan terjadi apabila masyarakat Indonesia berada pada tingkat ekonomi tertentu sehingga mereka tidak lagi memikirkan besarnya biaya perawatan tubuh untuk menjadikan diri mereka cantik.

Jika kita lihat lebih jauh, menjamurnya klinik - klinik kecantikan ini memang memungkinkan karena semakin banyak orang-orang yang masuk dalam kelompok kelas menengah baru. Menurut Bank Dunia, kelompok menengah atas adalah kelompok masyarakat yang memiliki pengeluaran sebesar US\$2-US\$ 20/ kapita/hari. Di Indonesia, pada tahun 2010, terdapat 130 juta orang dengan pengahasilan sebesar itu - 56,5\% dari total penduduk. Tahun 2003, jumlahnya hanya $37,7 \% 1$. Perkembangan kelompok menengah atas tersebut menyumbangkan $\quad 2,5 \%$ pendapatannya untuk kebutuhan akan kesehatan dan kecantikan². Meningkatnya penghasilan masyarakat Indonesia menimbulkan kelas konsumen baru yaitu kelompok masyarakat menengah baru. Kelompok ini mengalami pergeseran pola konsumsi, yang mulai

${ }^{1}$ Data dari majalah tempo edisi 20 26Februari 2012

${ }^{2}$ Data dari Tempo edisi tanggal 2026 Februari 2012 menyatakan bahwa uang masyarakat menengah terdistribusi pada : 17,2\% untuk perumahan; $2,1 \%$ untuk rekreasi; $3,6 \%$ untuk transportasi; $2,5 \%$ untuk produk dan jasa kesehatan; 41,7\% untuk makanan dan minuman non alkohol; 5,8\% untuk hotel dan catering; $7,3 \%$ untuk produk jasa rumah tangga; 5,2\% untuk minuman berakohol dan rokok; $7,1 \%$ untuk pendidikan; $1,7 \%$ untuk komunikasi; 3,6\% untuk pakaian dan alas kaki; 2,2\% untuk barang dan jasa lain 
memenuhi keinginankeinginan akan hiburan, wisata, kesehatan, dan pendidikan (Majalah Tempo edisi 20-26 Februari 2012). Kelompok kelas menengah baru ini membentuk kelas sosial tersendiri yang membedakan proses konsumsi mereka karena kelas sosial menunjukkan proses identifikasi yang berbeda (Abdullah, 2010). Kelompok masyarakat menengah baru inilah yang menjadi mangsa besar industri kapitalis.

\section{Tingginya kebutuhan}

masyarakat akan kecantikan membuat klinik-klinik kecantikan, dokter kecantikan, maupun salon-salon memberikan berbagai penawaran paket kecantikan. Mulai dari facial, massage, lulur, sampai pada tahap operasi. Akan tetapi yang menjadi permasalahan adalah klinik-klinik kecantikan ini mengubah posisi pasar bukan lagi mereka sebagai agen bisnis mencari pasar atau konsumen tetapi konsumen yang membutuhkan mereka sehingga konsumen seakan dibutakan . Bagi klinik-klinik kecantikan yang sudah memiliki nama, kita harus antri atau bahkan booking jauh-jauh hari agar tidak menunggu lama. Umumnya di klinikklinik kecantikan, konsumen 'dicekokin' berbagai macam obat yang saya yakini bahwa konsumen tidak memahami kandungan dari obat tersebut, apakah berbahaya (mengandung bahan-bahan kimia yang membahayakan, atau bahkan mengandung merkuri) atau bahkan bisa menyebabkan ketergantungan? Fenomena ini membuat klinik-klinik kecantikan melakukan pengobjekan konsumen. Pada posisi ini, konsumen berada pada posisi pasif dan mereka menaruh kepercayaan sepenuhnya kepada klinik-klinik kecantikan karena percaya kepada keprofesionalan mereka. Selain itu, obat-obat yang mereka berikan kebanyakan memberikan dampak ketergantungan jangka panjang. Misalnya para konsumen ini setiap bulan rutin melakukan perawatan wajah (facial) dalam kurun waktu tertentu ketika mereka tidak lagi melakukan perawatan wajah, wajah mereka menjadi 'rusak' dan 
lebih 'jelek' dari sebelum melakukan perawatan. Lebih parahnya, wanita-wanita yang mendambakan kecantikan ini tidak menyadarinya dampak ketergantungan pada klinik kecantikan sampai pada tahap muka mereka menjadi rusak.

\section{PEMBAHASAN}

\section{Pemaknaan Simbol Kecantikan oleh Wanita}

Definisi cantik dan mitos bagi perempuan memang berubah-ubah dari masa ke masa. Sejarah manusia mencatat, definisi cantik terusmenerus berubah. Di Eropa pada abad pertengahan kecantikan perempuan berkait erat dengan fertilitasnya, dengan kemampuan reproduksinya. Pada abad ke-15 sampai ke-17, perempuan cantik dan seksi adalah mereka yang punya perut dan panggul yang besar serta dada yang montok, yakni bagian tubuh yang berkait dengan fungsi reproduksi. Pada awal abad ke-19 kecantikan didefinisikan dengan wajah dan bahu yang bundar serta tubuh montok. Sementara itu, memasuki abad ke-20 kecantikan identik dengan perempuan dengan bokong dan paha besar. Akan tetapi, pada tahun 1965 model Inggris, Twiggy, yang kurus kerempeng menghentak dunia dengan tubuhnya yang tipis dan ringkih. Ia lalu digandrungi hampir seluruh perempuan seantero jagat dan menjadi ikon bagi representasi perempuan modern saat itu (Syata, 2012). Simbolsimbol kecantikan yang berubah dari waktu ke waktu merupakan proses rekonstruksi yang dilakukan oleh sekelompok orang yang memiliki kepentingan di dalamnya. Dalam konteks ini kelompok yang memiliki kepentingan adalah industri kecantikan. Simbol kecantikan bisa bermakna sesuatu yang diperlihatkan ataupun yang disembunyikan. Seperti yang dikatakan oleh Abdullah bahwa sebenarnya tubuh manusia awalnya adalah tubuh alami (natural body) tetapi kemudian mulai bergeser menjadi tubuh sosial atau fakta sosial (Abdullah, 2006: 138). Tubuh sosial atau fakta sosial bisa dipahami sebagai tubuh seorang individu adalah cerminan atau tuntutan dari 
tubuh yang diidam-idamkan masyarakat pada umumnya. Misalnya saja, tubuh ideal wanita bagi mayoritas orang adalah tubuh yang tinggi dan langsing sehingga secara sengaja atau tidak, wanita Indonesia 'membentuk' tubuhnya menjadi tubuh yang ideal. Ketika ini terjadi, maka tubuh bukan lagi menjadi urusan pribadi tetapi sudah menyangkut urusan orang lain.

Kecantikan di masa sekarang mulai menjadi ajang tontonan masyarakat. Lihat saja, di seluruh dunia pasti ada kontes kecantikan, mulai dari Miss Universe, Miss Indonesia, dan lain sebagainya. Bahkan kontes kecantikan tidak hanya berlaku untuk wanita saja tetapi juga untuk kalangan transgender. Bahkan, kecantikan juga tetap dipertahankan oleh kalangan selebriti ketika mereka bermain film di televisi tetapi mendapatkan peran sebagai wanita miskin. Artis ini tetap berdandan cantik dengan wajah penuh make up padahal peran mereka tidak membutuhkan 'kecantikannya'.

Wiasti (2010) menjelaskan bahwa konsep kecantikan juga bisa dibedakan antara yang klasik, modern, dan postmodern. Kecantikan klasik lebih mengarah pada ukuranukuran tubuh yang proporsional sesuai dengan konsepsi ideal yang digariskan oleh budaya, dan perpaduan antara kecantikan fisik dan mental (inner buauty), serta menekankan pada keselarasan hubungan dengan alam. Konsep kecantikan tradisional pada dasarnya berpijak kepada prinsip harmoni yang terkait secara struktural antar bagian tubuh sebagai efek alamiah dari anatomi dan fisiologis tubuh manusia. Kecantikan modern, lebih mengarah pada keseragaman atau universalitas, seperti kulit putih, dan ukuran-ukuran tubuh yang proporsional, dan semuanya mengarah pada halhal yang modern. Sedangkan kecantikan postmodern, adalah kecantikan yang mengacu pada makna pluralitas, heterogenitas dan bersifat sangat subyektif.

Wiasti juga memaparkan bahwa pada mulanya masyarakat Indonesia tidak memiliki orientasi makna kecantikan pada kulit putih tetapi lebih kepada kulit kuning langsat. Ini mungkin 
Rekonstruksi dan Manipulasi Simbol Kecantikan

bertujuan

untuk

mempertahankan kulit asli wanita Indonesia yang mayoritas adalah berkulit agak gelap. Melalui produk-produk kecantikan yang populer pada zaman itu, berkulit kuning langsat adalah impian seluruh wanita Indonesia. Akan tetapi, pergeseran makna cantik adalah kuning langsat menjadi cantik itu putih dimulai pada era 1985-an. Produk-produk kecantikan yang awalnya berorientasi pada kulit kuning langsat sekarang mulai bergeser kepada kulit putih. Oleh karena itu, produk-produk kecantikan tersebut mulai memasukkan unsur whitening ke dalam produknya.

Obesesi wanita Indonesia untuk tampil cantik sepertinya luar biasa besar. Ini dibuktikan dengan hadirnya salon-salon kecantikan dan klinik-klinik kecantikan yang selalu penuh sesak. Wanita Indonesia seperti dibutakan. Mereka bahkan rela mengalami kesakitan untuk mendapatkan kecantikan yang mereka inginkan. Mereka tidak segan-segan untuk melakukan tindak kekerasan terhadap tubuhnya, dengan cara mentato, melukis (body paintings), mengkeriting dan meluruskan (rebonding), mencukur dengan berbagai model/bentuk, mengecat berwarna-warni rambutnya, mencabut bulu kaki, suntik pemutih, hingga sedot lemak. Oleh karena itu, hal yang paling ditakuti oleh perempuan adalah pekembangan dalam tubuhnya ketika ia menghitam, menggemuk atau menua (Wiasti, 2010). Perempuan selalu menderita ketika ingin menjadi sosok yang cantik, karena semakin kuat posisi ideal perempuan, sebenarnya semakin berat upaya yang dilakukan untuk membangun kecantikan (Melliana, 2006 dalam Wiasti, 2010).

Kecantikan tidak bisa dilepaskan dengan keindahan fisik atau tubuh. Bentuk tubuh yang ideal adalah langsing, tidak kelebihan lemak pada bagian-bagian tubuh atau proporsional, perut datar, payudara kencang, pinggang berlekuk, dan pantat sintal, itulah yang dikatakan cantik (Melliana, 2006: 4 dalam Wiasti, 2010). 
Sementara itu, Yulianto (2007: 36 dalam Wiasti, 2010), mengatakan bahwa idealisme kecantikan perempuan kini diidentikkan dengan kulit putih atau wajah Indo. Berbeda dengan keduanya, Kusuma Jaya mengatakan bahwa kecantikan itu pada hakikatnya adalah kemampuan tampil menarik secara keseluruhan, bukan bagian per bagian (Jaya, 2007: 14 dalam Wiasti, 2010). Akan tetapi, menurut Abdullah, konstruksi kecantikan tubuh pada dekade ini adalah mengacu pada referensi kesegaran, mengarah pada sesuatu yang halus, rapi, yang semuanya bergeser ke arah segar (Abdullah, 2006 dalam Wiasti, 2010).

\section{Gaya Hidup Kelas Konsumen} Baru dan Pengobjekan Konsumen

Berangkat dari pemikiran Douglas \& Isherwood yang mengatakan bahwa gaya hidup yang dilihat dari tingkah laku konsumsi merupakan penanda identitas (Douglas
\& Isherwood, 1980) yang berdasarkan asumsi bahwa barang-barang konsumsi merupakan alat komunikasi (Goffman dalam Abdullah, 2010) kita bisa menjelaskan fenomena ini

Konsumsi kecantikan bagi masyarakat menengah baru merupakan suatu bentuk identitas baru bagi mereka karena mereka mulai sadar mengenai pentingnya terlihat cantik dan berkelas. Kecantikan bukan lagi konsumsi pribadi untuk kepuasan semata tetapi kecantikan merupakan wacana baru yang hadir dalam kelas sosial mereka. Kecantikan mulai diperbincangkan dan negosiasikan demi eksistensi kelas sosial yang melekat pada identitas mereka. Fenomena ini sejalan dengan apa yang pernah dikatakan oleh Foucault bahwa keberadaan tubuh diproduksi oleh wacana (Foucault, 1990) dalam bentuk media seperti iklan, film, televisi, pembicaraan publik, dan lain sebagainya sehingga keberadaan tubuh menjadi penting. 
Rekonstruksi dan Manipulasi Simbol Kecantikan

Munculnya klinik-klinik kecantikan di Indonesia sebenarnya diperuntukkan bagi masyarakat kelas menengah khususnya kelas menengah baru. Ini dikarenakan mereka memiliki cukup uang yang memungkinkan mereka 'memproduksi' kecantikan yang mereka inginkan melalui bantuan teknologi yang canggih dan dokter spesialis yang profesional. Mereka juga mulai menyadari pentingnya kesehatan tubuh khususnya kesehatan kulit. Lihat saja fenomena artis yang rela menghabiskan uang sampai ratusan juta rupiah untuk terlihat lebih cantik dan lebih muda. Walaupun alasan mereka adalah wajah sebagai modal utama sebagai seorang entertaint.

Kecantikan merupakan hal yang wajib diperoleh meskipun dengan cara yang menyakitkan seperti operasi dan suntik botok. Terlepas dari kasus artis yang memang membutuhkan kecantikan untuk menunjang pekerjaan mereka, masyarakat umum ternyata juga mengidamidamkan wajah cantik seperti selebriti. Mereka rela mengeluarkan uang yang banyak untuk mendapatkan wajah yang mereka inginkan. Akan tetapi, keinginan untuk terlihat cantik hanya sebatas keinginan dan kesadaran untuk mendapatkannya. Masyarakat Indonesia pada umumnya belum memiliki pengetahuan yang cukup tentang kecantikan. Secara umum, bukan saja pengetahuan tentang kecantikan yang belum begitu dimengerti oleh masyarakat Indonesia tetapi pengetahuan kesehatan secara keseluruhan. Misalnya saja, ketika berobat ke dokter, masyarakat Indonesia hanya memberikan keluhankeluhan mereka kepada dokter tanpa bertanya lebih jauh mengenai penyakit mereka dan mengapa hal itu bisa terjadi. Mereka begitu percaya kepada dokter tentang penyakit mereka tanpa melakukan cross check kepada dokter lain atau mencari tahu lebih banyak menggunakan media internet atau diskusi mengenai kesehatan di seminar-seminar. Mereka juga tidak memahami kandungan obat yang mereka 
konsumsi apakah aman atau tidak bagi kesehatan mereka.

Konsep rasa percaya yang begitu besar kepada dokter juga bisa diterapkan dalam kasus menjadi cantik dengan pergi ke salon dan klinik kecantikan. Wanita Indonesia yang tidak memiliki pengetahuan yang memadai mengenai kesehatan kulit, produk kecantikan, dan sebagainya akan lebih mudah menerima masukan-masukan dari 'sang ahli'. Mereka sangat percaya dengan 'jualan' orangorang salon maupun dokter kecantikan tentang produk yang akan mereka pakaikan kepada kita. Seringkali konsumen mengiyakan atau tidak berpikir panjang tentang efek samping yang disebabkan oleh produk tersebut. Konsumen terkadang juga tidak berpikir tantang kesesuaian produk dengan kulit mereka, bahan produk tersebut, dan semacamnya.

$$
\text { Konsumen seakan }
$$

diperdaya dan tanpa sadar mereka telah melakukan pengobjekan. Mereka mempengaruhi konsumen tanpa memberi ruang kepada konsumen untuk berpikir panjang. Padahal konsumen adalah subjek dari konsumsi kecantikan. Konsumen berkewajiban mempertimbangkan berbagai macam hal sebelum mengambil keputusan untuk melakukan hal yang mereka tawarkan. Seharusnya sebagai subjek, konsumen lebih aktif untuk mempertanyakan argument- argumen mereka tetapi kerena kita tidak memiliki pengetahuan tentang kesehatan, maka konsumen cendrung untuk menurut dan menyanggupi apa yang dikatakan oleh sang ahli.

\section{Konstruksi Makna Kecantikan oleh Industri Kapitalis melalui Iklan}

Konstruksi makna kecantikan di dunia yang cendrung sama, tidak bisa dilepaskan dari peran industri kapitalis yang bermain di dalamnya. Industri kapitalis memiliki kepentingan yang besar karena dengan merekonstruksi makna kecantikan di seluruh dunia, mereka bisa mensuplai produk-produknya melalui klinik kecantikan, salon, supermarket bahkan bisa kita temukan di 
warung-warung di dekat rumah kita.

Industri kapitalis tidak bisa bergerak sendiri tanpa ada perantara diantara mereka dan konsumen. Iklan adalah salah satu cara terbaik untuk memperkenalkan produk mereka sehingga konsumen terperdaya dan menjadi salah satu konsumen setia mereka. Iklan khususnya televisi, yang diciptakan oleh industri kapitalis sehingga 'menyihir' semua penonton untuk ikut dalam konstruksi besar yang telah mereka siapkan.

Peter L. Berger dan Thomas Luckman (dalam Syata, 2012) mengatakan bahwa salah satu proses kelahiran konstruksi sosial media massa adalah tahap menyiapkan

materi konstruksi. Dalam tahap tersebut ada tiga hal penting, yaitu : 1) Keberpihakan media massa kepada kapitalisme. Dalam arti, media massa digunakan oleh kekuatankekuatan kapital untuk menjadikan media massa sebagai mesin penciptaan uang dan penggandaan modal.
Semua elemen media massa, termasuk orang-orang media massa

berpikir untuk melayani kapitalisnya, ideologi mereka adalah membuat media massa laku di masyarakat. 2) Keberpihakan semu kepada masyarakat. Bentuk dari keberpihakan ini adalah empati, simpati, dan berbagai partisipasi kepada masyarakat, namun ujung-ujungnya adalah untuk menjual berita dan menaikkan rating untuk kepentingan kapitalis. 3) Keberpihakan kepada kepentingan umum. Bentuk keberpihakan kepada kepentingan umum dalam arti sesungguhnya sebenarnya adalah

visi setiap media massa, namun, akhir-akhir ini visi tersebut tak pernah menunjukkan jati dirinya, walaupun slogan-slogan tentang visi ini tetap terdengar.

Dalam

konstruksi

pemikiran masyarakat Indonesia, mereka meyakini bahwa 'cantik' itu berbadan putih layaknya masyarakat Korea Selatan dan Chinese. Hal ini disebabkan oleh 
masifnya iklan yang ada di televisi dan media sosial. Para remaja percaya bahwa mereka harus menjadikan tubuh mereka lebih putih dari aslinya. Dampak dari konstruksi besar industri kapitalis ini membuat mereka berbondong- bondong membeli produk kecantikan yang bisa membuat kulit mereka putih, bersih, dan bersinar. Mereka percaya bahwa setelah menjadi putih mereka akan terlihat lebih cantik dan menarik.

Sungguh kejadian yang ironis tetapi menarik. Foucault mengatakannya sebagai "produksi kekuasaan", kekuasaan tidak bertumpu pada satu titik sentral termasuk tidak hanya pada pihak-pihak yang dominan, melainkan tersebar di seluruh masyarakat (tidak ada seorang pun yang memilikinya) (John Lechte, 2001 dalam Fitryarini, 2009). Kuasa bukanlah milik raja, boss, presiden, atau pejabat, tetapi dalam bentuk strategi. Kekuasaan tidak bekerja melalui penindasan atau represi, melainkan melalui normalisasi yang positif dan produktif, yaitu melalui wacana. Iklan, adalah salah satu tayangan media yang menyebarkan kuasa (strategi) tentang normalisasi tubuh perempuan (Fitryarini, 2009).

Foucault juga mengatakan, "Kekuasaan yang mendefinisikan pengetahuan, melakukan penilaian apa yang baik dan yang buruk, yang boleh dan tidak boleh, mengatur perilaku, mendisiplinkan dan mengontrol segala sesuatu, dan bahkan menghukumnya. Artinya, subyek manusia sebagai individu, juga dibentuk dan diatur oleh rezim kekuasaan." (Ngangi, 2001). Dalam hal ini kekuasaan adalah milik kapitalis sebagai orang yang berkuasa dan memegang wacana mengenai makna kecantikan.

Iklan sebagai Media Rekonstruksi Makna Kecantikan

Seperti yang sudah dibahas di atas, tidak bisa dipungkiri bahwa rekonstruksi makna kecantikan paling dominan dilakukan oleh televisi melalui media iklan. Iklan bersifat rayuan dan 
Rekonstruksi dan Manipulasi Simbol Kecantikan

ajakan yang dilakukan oleh pembuat iklan untuk 'menjual' produk mereka melalui visualisasi-visualisasi yang seakan berupa realitas kehidupan dalam masyarakat. Iklan kecantikan misalnya, begitu menyolok dan memberikan kesan seolah-olah yang terpenting dalam hidup ini adalah wajah dan tubuh yang cantik dan dapat memikat perhatian lawan jenis. Melalui pesan-pesannya yang sugestif dan subliminal, iklan kecantikan mengaktifkan dorongan- dorongan bawah sadar yang mendominasi kehidupan manusia. Iklaniklan kecantikan tersebut memperkokoh mitos-mitos budaya paling kuat, yaitu pentingnya daya tarik fisik dan usia muda, terutama bagi kaum perempuan (Fitryarini, 2009). Marshall McLuhan menyebut televisi sebagai hot media adalah media paling efektif untuk membangkitkan dan melumpuhkan kesadaran massa dalam jangka tak bisa ditentukan. Di belahan dunia manapun logika dasar televisi memang demikian: menghipnotis orang sedemikian rupa, hingga mereka tunduk di bawah kekuasaannya, untuk kemudian digiring berbondong-bondong agar mengkonsumsi produk-produk yang ditawarkan (Mc Quail, 2002:302 dalam Fitryarini, 2009).

Berger dan Luckmann mengatakan "realitas adalah kontruksi sosial". Kontruksi sosial memiliki tiga kekuatan. Pertama, bahasa memberikan mekanisme konkret, sehingga budaya mempengaruhi pikiran dan tingkah laku individu. Kedua, kontruksi sosial dapat mewakili kompleksitas dalam satu budaya tunggal. Ketiga, bersifat konsisten dengan masyarakat dan waktu. “Kontruksi sosial merupakan sebuah pandangan kepada kita bahwa semua nilai, ideologi, dan institusi sosial adalah buatan manusia" (Ngangi, 2001).

Berger juga menjelaskan mengenai konstruksi sosial dalam masyarakat, yaitu : pertama, proses eksternalisasi yang menjadi bagian dari proses penciptaan realitas dalam berbagai bentuk. Proses 
ini dapat melibatkan individu maupun kelompok atau institusi. Kedua, proses objektivasi yang merupakan proses integrasi nilai ke dalam fakta sosial objektif yang dapat diterima oleh publik. Identitas bersama terbentuk ketika aspekaspek identitas diakui dan diterima secara kolektif. Ketiga, proses konstruksi terkait dengan proses internalisasi yang merupakan tahapan untuk menjadikan pengetahuan, nilai dan tindakan menjadi milik individu yang melahirkan komitmen sikap dan perilaku individual (Berger dan Luckmann, 1979).

Oleh karena itu, iklan yang terus-menerus ditayangkan di dalam televisi dan selalu kita konsumsi, lamakelamaan akan mempenagruhi pandangan kita terhadap sesuatu. Misalnya seperti contoh yang sudah dibahas di atas bahwa iklan pemutih tubuh adalah iklan yang sangat mempengaruhi wanita Indonesia khususnya kaum remaja. Mereka berlomba-lomba untuk 'memutihkan' diri mereka dengan berbagai cara, misalnya dengan menggunakan lotion tubuh, perawatan tubuh di salon sampai kepada suntik vitamin C, yang sebenarnya penggunaannya sudah dilarang karena membahayakan konsumen.

\begin{tabular}{lrr}
\multicolumn{2}{c}{ Wanita, } & khususnya \\
remaja sangat & mudah \\
termakan & 'rayuan' & iklan
\end{tabular}
yang menjanjikan kecantikan seperti yang mereka visualkan melalui model yang mereka gunakan. Akan tetapi setelah mereka mengkonsumsi produk tersebut, impian mereka ternyata tidak selalu menjadi kenyataan karena banyak produk yang ditawarkan tidak sesuai dengan iklan mereka.

Untuk kalangan menengah ke atas, konsumsi kecantikan tidak lagi menggunakan produkproduk kecantikan yang ada di dalam iklan televisi. Mereka memiliki tempat tersendiri yang mereka yakini bisa membantu mereka untuk terlihat lebih cantik. Misalnya salon-salon terkenal maupun dokter kulit langganan. Meskipun begitu, mereka tetap saat bagian dari konstruksi besar para industri kapitalis yang juga konsumen dari iklaniklan televisi. Meskipun mereka adalah kalangan yang 
berbeda dengan kalangan masyarakat biasa, pemahaman mereka tentang makna kecantikan tidak lah berbeda dengan masyarakat biasa. Itu berarti bahwa konstruksi kecantikan yang dibuat atas kepentingan industri kapitalis melalui media iklan sudah berhasil dengan baik dan tidak mengenal kelas-kelas sosial dalam masyarakat.

\section{Kesimpulan}

Dari uraian di atas, kita bisa menyadari bahwa simbol dan makna kecantikan adalah sebuah konstruksi besar yang dirancang oleh industri kapitalis untuk memperdaya wanita-wanita di Indonesia sehingga menjadi konsumen produk kecantikan mereka. Meskipun untuk mencapai tahap ini, industri kapitalis membutuhkan mediator untuk menyampaikan pesan-pesan mereka kepada calon konsumen. Sejalan dengan yang dikatakan Foucault bahwa keberadaan tubuh diproduksi oleh wacana (Foucault, 1990), jawaban yang paling menguntungkan adalah dengan bantuan media Iklan.

Konstruksi makna dan simbol kecantikan tidak begitu saja diterima oleh masyarakat. Harus ada proses-proses yang dilewatinya. Berger mengatakan bahwa ada tiga proses, yaitu : 1) proses eksternalisasi yang menjadi bagian dari proses penciptaan realitas dalam berbagai bentuk.

2) Proses objektivasi yang merupakan proses integrasi nilai ke dalam fakta sosial objektif yang dapat diterima oleh publik. 3) Proses konstruksi terkait dengan proses internalisasi yang merupakan tahapan untuk menjadikan pengetahuan, nilai dan tindakan menjadi milik individu yang melahirkan komitmen sikap dan perilaku individual (Berger dan Luckmann, 1979). Konstruksi besar ini secara tidak langsung disepakati oleh industriindustri kecantikan seluruh dunia. Entah secara sengaja atau tidak mereka memasukan unsur- unsur yang sama untuk menjelaskan simbol dan makna kecantikan, seperti putih, langsing, rambut hitam lurus, 
dan lain sebagainya. Oleh sebab itu, mereka berlombalomba menciptakan produk pemutih tubuh yang dijual dengan bebas tanpa bisa diproteksi keamanannya.

Keinginan untuk menjadi cantik dengan percaya kepada produk-produk tersebut dan tidak diimbangi dengan pengetahuan yang cukup mengenai kecantikan dan kesehatan menyebabkan terjadinya pengobjektivikasi konsumen oleh produsen atau klinik-klinik kecantikan karena pikiran mereka secara tidak langsung 'dicekokin' dengan kebenaran realitas yang diciptakan oleh industri kecantikan. Konsumen seakan tidak dibiarkan memilih untuk menjadi dirinya sendiri karena tubuh seorang individu sudah mengalami banyak 'tuntutan' dari berbagai pihak. Seperti yang dikatakan oleh Abdullah bahwa tubuh sudah mengalami fakta sosial di mana tubuh bukan lagi sepenuhnya milik seorang individu tetapi tubuh sudah menjadi bagian dari kelompok masyarakat.

\section{DAFTAR PUSTAKA}

Abdullah, Irwan. 2001. Seks, Gender $\mathcal{E}$ Reproduksi Kekuasaan. Yogyakarta. Terawang Press.

$\begin{array}{lr}\text { Konstruksi } & 2009 . \\ \text { Reproduksi } & \text { dan } \\ \text { Kebudayaan. } & \\ \text { Yogyakarta: } & \text { Pustaka } \\ \text { Pelajar. } & \end{array}$

Allen, A.H.B. 1995. The Meaning of Beauty. Philosophy, Vol. 30, No. 113 pp. 112-130. Cambridge University Press.

Brand, Peg Zeglin. 1999. Beauty Matters. The Journal of Aesthetics and Art Criticism, Vol. 57, No. 1, pp. 1-10. Wiley

Doherty, Sandra Beth. 2008. Cosmetic Surgery and the Beauty Regime in Lebanon. Middle East Report, No. 249, Shrinking Capital: The US in the Middle East, pp. 28-31. MERIP

Dunbar, Howard. Jackson. 1972. Free clinics for young people. Social Work, Vol. 17, No. 5, 
pp. 27-34. Oxford Journals.

English, Basil G. Michael R. Solomon, Richard D. Ashmore. 1994. Beauty before the Eyes of Beholders: The Cultural Encoding of Beauty Types in Magazine Advertising and Music Television. Journal of Advertising, Vol. 23, No. 2, pp. 49-64. Tylor \& Francis, Ltd.

Fitryarini, Inda. 2009. Iklan dan Budaya Popular: Pembentukan Identitas Ideologis Kecantikan Perempuan oleh Iklan di Televisi. Vol. 6, No. 2, pp. 119-136. Jurnal

Komunikasi.

Hearne, Brian. 1990. Beauty Is Truth, Truth Beauty. The Furrow, Vol. 41, No. 1, pp. 9-14

Millard, Jennifer. 2009. Performing Beauty: Dove's "Real Beauty" Campaign. Symbolic Interaction, Vol. 32, No. 2, pp. 146-168. Wiley.

Pearson, Gerald H. 1924. A Clinic for Women and Children. The Public
Health Journal, Vol. 15, No. 10, pp. 452-455. Canadian Public Health Association.

Sontag, Susan. 2005. An Argument about Beauty. Daedalus, Vol. 134, No. 4, 50 Years, pp. 208-213. The MIT Press.

Starr, G. Gabrielle. 2002. Ethics, Meaning, and the Work of Beauty. Eighteenth- Century Studies, Vol. 35, No. 3, Aesthetics and the Disciplines, pp. 361378. The Johns Hopkins University Press.

Syata, Novitalista. 2012.

Makna Cantik di

Kalangan Mahasiswa dalam Perspektif

Fenomenologi. Skripsi.

Fakultas Ilmu Sosial dan Ilmu Politik Universitas Hasanudin. Makasar.

Toelken, Barre. 2004. Beauty Behind Me; Beauty Before. The Journal of American Folklore, Vol. 117, No. 466 pp. 441-445. University of Illinois Press. 
Jurnal Hawa Vol. I No. I Januari-Juni 2019

Wiasti, Ni Made. Redefinisi

Kecantikan Dalam

Meningkatkan

Produktivitas Kerja

Perempuan Bali, di Kota

Denpasar. Fakultas

Sastra Universitas

Udayana Denpasar.

Wuori, G. K. 1994. Beauty.

The Massachusetts

Review, Vol. 35, No. 1,

pp. 27-42. The

Massachusetts Review,

Inc 